\title{
VNÍMANÁ AKADEMICKÁ ÚČINNOST ŽÁKŮ STŘEDNÍCH ŠKOL V ČESKÉM JAZYCE A V MATEMATICE, TVORBA VÝZKUMNÉHO NÁSTROJE
}

\author{
JANA DRABEROVÁ
}

\begin{abstract}
Cílem předkládané studie bylo vytvoření výzkumného nástroje pro měření vnímané akademické účinnosti žáků středních škol, který v českém prostředí zatím není k dispozici. Výzkumný soubor tvoří 1717 žáků středních škol ze všech krajů České republiky. Do výzkumu byla zahrnuta střední odborná učiliště, střední odborné školy a gymnázia. Žáci vyplňovali dotazník pro český jazyk a pro matematiku. Výsledný výzkumný nástroj vykazuje vysokou reliabilitu, ověřena byla také jeho validita. Dále se ukázal významný vztah mezi naměřenou vnímanou akademickou účinností a tím, zda žáci hodnotí předmět jako svůj oblíbený. Potvrzena byla také souvislost se školní známkou, typem studované školy, specifickými poruchami učení a chování a dalšími proměnnými.
\end{abstract}

Klíčová slova: vnímaná akademická účinnost, self-efficacy, vývoj dotazníku, střední škola, český jazyk, matematika https://doi.org/10.14712/23366486.2019.1

\section{Teoretická východiska}

Teoretickým rámcem konceptu vnímané akademické účinnosti je sociálně-kognitivní teorie A. Bandury (1997), který vymezil koncept self-efficacy (vnímaná osobní účinnost) jako přesvědčení jedince o jeho vlastních schopnostech potřebných k dosažení určitého cíle. Tato přesvědčení ovlivňují výběr aktivit a motivační úroveň jedince, čímž významně přispívají k tvorbě jeho znalostí a dovedností. Dle A. Bandury (1997) se jedná o konstrukt multidimenzionální. Další autoři toto Bandurovo přesvědčení potvrdili a doplnili o poznání, že není možné obsáhnout specifika jednotlivých oblastí a úkolů v obecné rovině a nelze tedy hovořit o uspořádání hierarchickém (Bong, Clark, 1999; Bong, Skaalvik, 2003).

Ve vztahu ke studijním aktivitám je užíván termín academic self-efficacy (vnímaná akademická účinnost ${ }^{1}$ ). A. Bandura (1997) definoval tento pojem jako přesvědčení žáka o vlastních schopnostech potřebných $\mathrm{k}$ dosažení daných typů studijních výkonů. Prvotní studie v této oblasti potvrdily, že žáci se stejnou úrovní kognitivních schopností se liší ve studijních výkonech v závislosti na síle jejich vnímané akademické účinnosti (Bandura, Schunk, 1981; Schunk, 1984). Souvislost se školními výkony byla ověřena i dalšími výzkumy (např. Altunsoy et al., 2010; Caprara et al., 2008; Diseth, 2011).

V české literatuře se můžeme setkat s různými překlady tohoto pojmu. Abychom dodrželi kontinuitu prací autorky, používáme termín vnímaná akademická účinnost, ačkoli si jsme vědomi nepřesnosti překladu. 
Z hlediska prožívání a motivace se ukazuje, že žáci s nízkou úrovní vnímané akademické účinnosti častěji pochybují o svých schopnostech vyřešit zadaný úkol, pracují s menším nasazením, jsou méně pohotoví, a narazí-li na překážky, brzy se vzdávají. Mohou se cítit bezradní a zoufalí, pocitovat úzkost a strach. Oproti tomu žáci s vysoce vyvinutou vnímanou akademickou účinností se pouštějí i do složitějších úkolů, překážky pro ně znamenají výzvy, práce je naplňuje a vzrušení s ní spojené vnímají spiše jako adrenalin (Williams, Williams, 2010; Zimmerman, Bandura, 1994). Vzhledem k významnému vlivu vnímané akademické účinnosti na studijní výkony žáků, na jejich studijní aspirace a celkový vztah ke vzdělávání si toto téma zaslouží pozornost odborníků v edukační praxi.

V českém prostředí bylo téma vnímané akademické účinnosti delší dobu opomíjeno, v posledních letech se však pomalu dostává do popředí zájmu. Objevují se bakalářské a diplomové práce zabývající se tímto tématem z různých úhlů pohledu (např. Kučerová, 2015; Lávičková, 2016; Ptáčková, 2014; Vozková, 2014), publikována byla také rozsáhlejší studie I. Smetáčkové a A. Vozkové (2016).

\section{Cíl výzkumu}

Hlavním cílem předkládaného výzkumu je vytvoření výzkumného nástroje, který by umožnil změřit vnímanou akademickou účinnost (dále VAÚ) u žáků stř̌edních škol. Motivací pro jeho vytvoření je přenesení teoretických poznatků o VAÚ do praxe. Dále také skutečnost, že v České republice podobný výzkumný nástroj k dispozici není. Vzhledem $\mathrm{k}$ tomu, že VAÚ má významný vliv na školní výkon žáků a přispívá $\mathrm{k}$ jejich celkové školní spokojenosti, mohou být informace o úrovni VAÚ jednotlivých žáků cenným vodítkem pro učitele a další pedagogické pracovníky, na jehož základě mohou svým žákům lépe porozumět.

Pilotní studií $\mathrm{k}$ tomuto výzkumu je diplomová práce autorky (Draberová, 2012), v rámci které již pokus o vytvoření výše popsaného výzkumného nástroje proběhl (výzkumný vzorek tvořilo přes 600 žáků pražských gymnázií). Tento výzkum si klade za cíl revidovat již vytvořený výzkumný nástroj, rozšíriti výzkumný soubor o žáky dalších typů škol a oborů a zahrnout do výzkumu více krajů České republiky.

Validitu výzkumného nástroje ověřujeme na základě následujících předpokladů: VAÚ souvisí se školní známkou, VAÚ souvisí s hodnocením zvládnutí náročných školních situací, VAÚ souvisí s prožitky, které žáci v těchto situacích zažívají, VAÚ žákủ souvisí s hodnocením VAÚ jejich učiteli. Mimo prověřování validity se zaměříme také na porovnání naměřené VAÚ v českém jazyce a matematice (zde vzhledem k doménové specifičnosti konceptu předpokládáme rozdíly), porovnání VAÚ s ohledem na pohlaví a věk respondentů, zjištována bude rovněž souvislost se specifickými poruchami učení a chování.

\section{Metodologie}

\subsection{TVORBA DOTAZNÍKU}

Při konstrukci výzkumného nástroje jsme vycházeli z doporučení A. Bandury (2006), která zdůrazňují vhodnost zaměřit se na konkrétní oblast fungování člověka, spíše než na 
obecná dotazování bez konkrétního rámce, ve kterém činnost probíhá. Rozhodli jsme se proto sledovat VAÚ v jednotlivých školních předmětech. Vytvořen byl jeden dotazník, který může být použit pro různé školní předměty (v rámci tohoto výzkumu byl sledován český jazyk a matematika), takže zadavatel získá informace o VAÚ prímo v konkrétním předmětu. Zvolili jsme tedy jakousi střední cestu, kdy se nedotazujeme na obecnou VAÚ pro studium jako celek, ovšem ani necílíme na činnosti specifické pouze pro jeden konkrétní předmět, což by významně omezilo možnosti využití dotazníku.

Základním východiskem pro tvorbu dotazníku, byl dotazník vytvořený v rámci pilotní studie (Draberová, 2012). Tento dotazník vykazoval dobrou reliabilitu (Cronbachova alfa $=0,93$ ) i validitu, faktorovou analýzou byly zjištěny čtyři faktory. První z faktorů nazvaný reflexe vlastnich kompetencí zachycoval žákovo presesvědčení o tom, jak zvládá předmět jako celek (zahrnuje respondentovy obavy z nových úkolů, jeho víru ve vlastní schopnosti zvládat překážky, které se při dosahování cíle objeví a jeho přesvědčení o svých schopnostech nabyté znalosti a dovednosti efektivně využít). Tento faktor koreloval s celkovým hrubým skórem nejsilněji. Druhý faktor nazvaný strategie řešení problémů zahrnoval přesvědčení žáka o tom, zda je schopen svou práci efektivně organizovat, dokáže-li odhadnout důležitost informací, se kterými pracuje a je-li schopen výsledky své práce vhodně reflektovat. Společným jmenovatelem třetího a čtvrtého faktoru byly vnější vlivy. Třetí faktor sledoval podporu a oceněni od učitele a také způsob výuky daného předmětu. Čtvrtý se týkal toho, jak jedinec vnímá očekávání ze strany rodičù a podporu, kterou mu poskytují.

Pro účely nového dotazníku byly vybrány položky z prvních dvou faktorů, které nejlépe postihovaly koncept VAÚ. K těmto položkám byly přidány další tak, aby byly tyto dva faktory doplněny. Inspirací pro tvorbu nových položek byly následující zahraniční dotazníky: Children's Self-Efficacy Scale (Bandura, 2006), Children's Perceived Self-Efficacy Scales (CPSE) (Pastorelli et al., 2001), The Morgan-Jinks Student Efficacy Scale (MJSES) - subškála Children's Perceived Academic Self-Efficacy (Jinks, Morgan, 1999), Motivated Strategies for Learning Questionnaire (MLSQ) (Pintrich, DeGroot, 1990), Student Self-Report of Academic Self-Efficacy (Hoover-Dempsey, Sandler, 2005), Student Approaches to Learning - subškála Perceived Self-Efficacy (Marsh et al., 2006), Problem Solving and Logical Reasoning Survey (Poynton et al., 2006), Self-Efficacy Questionnaire for Children (SEQ-C) (Muris, 2001).

Výsledný dotazník, který byl žákům prezentován, zahrnoval 24 tvrzení, ke kterým se žáci vyjadřovali na šestibodové škále. Stejně jako u předchozího výzkumu byl za účelem validizace přidán popis čtyř náročných školních situací. U každé z nich měl respondent ohodnotit, na kolik procent si myslí, že v ní bude úspěšný. Dále bylo u každé situace uvedeno pět pozitivních (zábava, zájem, adrenalin, jistota, výzva) a pět negativních (strach, nervozita, zoufalství, naštvání, stres) prožitků. Úkolem respondenta bylo označit na čtyřbodové škále, jak intenzivně tento prožitek v dané situaci zažívá. Zjištovány byly demografické údaje a údaje o vyplňovaném předmětu (školní známka, která žákovi z předmětu aktuálně vychází i ta, kterou měl na posledním vysvědčení, zda patří zvolený předmět k jeho oblíbeným, zda je pro něj jeho obsah zajímavý a jak mu vyhovuje způsob jeho výuky). Dotazník vyplňovali respondenti nejprve pro český jazyk, následně pro matematiku. Pilotně byl sestavený dotazník otestován jednou tř́dou střední školy, kdy šlo především o ověření srozumitelnosti formulací. 


\subsection{SBĚR DAT}

Předkládaný výzkum byl zaměřen na žáky středních škol. Protože nelze předem vyloučit rozdíly VAÚ s ohledem na studovaný typ školy a studijní obor, zahrnoval výzkumný soubor kromě gymnázií i ty studijní obory středních odborných učilišt' (dále SOU) a středních odborných škol (dále SOŠ), které dle statistické ročenky školství (Ministerstvo školství, mládeže a tělovýchovy, 2015) studovalo ve školním roce 2013/2014 nejvíce žáků (viz tabulka 1).

Tabulka 1 Obory s nejvyššim počtem absolventů za školní rok 2013/14

\begin{tabular}{|c|l|c|}
\hline Kód oboru & \multicolumn{2}{|c|}{ Počet absolventů za školní rok 2013/14 } \\
\hline $79-41-\mathrm{K}$ & gymnázium SOS & 22776 \\
\hline \multicolumn{2}{|c|}{ SOU } & 6668 \\
\hline $63-41-\mathrm{M}$ & ekonomika a administrativa & 2789 \\
\hline $65-42-\mathrm{M}$ & hotelnictví a turismus & 2610 \\
\hline $18-20-\mathrm{M}$ & informační technologie \\
\hline & \multicolumn{2}{|c|}{} \\
\hline $65-51-\mathrm{H}$ & kuchař-číšník & 2747 \\
\hline $23-68-\mathrm{H}$ & mechanik opraváŕ motorových vozidel & 2246 \\
\hline $69-51-\mathrm{H}$ & kadeřník & 1766 \\
\hline
\end{tabular}

Školy byly vybrány tak, aby pokryly co nejvíce krajů České republiky. Zastoupení oborů z jednotlivých krajů ve výzkumném souboru je blíže popsáno v tabulce 2 .

Jednotlivé školy byly oslovovány e-mailem s vysvětlením záměru a prosbou o spolupráci na výzkumu. Celkem bylo osloveno 427 škol. Dotazníky bylo možné vyplňovat online, nebo v papírové podobě. Veškeré potřebné instrukce k vyplňování obsahoval samotný dotazník. Sběr dat probíhal od prosince 2015 do konce června 2016. Průměrná doba vyplňování dotazníku byla 15 minut.

\subsection{POPIS VÝZKUMNÉHO SOUBORU}

Celkem bylo sebráno 1942 dotazníků, z toho 489 v papírové podobě a 1453 ve formě elektronické. Po sjednocení dat bylo vyřazeno 225 respondentů, ${ }^{2}$ analyzovaný soubor tedy sestává z 1717 respondentů s následujícími charakteristikami. Z hlediska pohlaví tvoří výzkumný soubor 919 dívek a 792 chlapců (6 respondentů neuvedlo jméno ani pohlaví). Věkové rozložení souboru se pohybuje od patnácti do dvaceti jedna let. Nejpočetněji je zde zastoupena věková kategorie šestnáctiletých $(31,6 \%)$, sedmnáctiletých $(26,2 \%)$ a osmnáctiletých žáků $(17,4 \%)$.

Zastoupení zvolených oborů je poměrně vyrovnané. Nejvíce žáků zapojených do výzkumu studovalo učební obor kuchař-číšník (18,7 \%), nejméně učební obor mechanik

215 dotazníků bylo vyřazeno pro zjevnou nedůvěryhodnost dat, 139 respondentů studovalo jiný, než požadovaný obor (65 veřejnosprávní činnost, 52 ekonomické lyceum, 16 cukrář, 6 instalatér) a 71 respondentů bylo vyřazeno pro nevyplnění některých položek vlastního dotazníku. 


\begin{tabular}{|c|c|c|c|c|c|c|c|c|c|c|c|c|c|c|c|c|}
\hline & 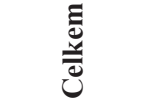 & $\widehat{\vartheta}$ & તี & $\hat{\sigma}$ & $\stackrel{\mathscr{F}}{ \pm}$ & ర్ర & $\stackrel{ }{=}$ & bे & $\nabla$ & 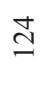 & 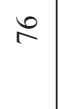 & ৯े & $\stackrel{n}{n}$ & $\Xi$ & $\exists$ & 三 \\
\hline & 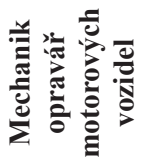 & 0 & $F$ & శี & $\tilde{N}$ & 0 & 0 & $\tilde{N}$ & $n$ & 0 & $\tilde{\sim}$ & 0 & 0 & 0 & $\beth$ & $\stackrel{2}{n}$ \\
\hline & 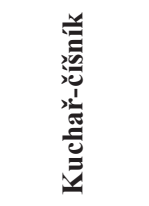 & $r$ & $\vec{b}$ & 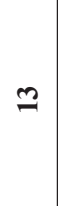 & '2 & 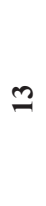 & $\vec{m}$ & $\grave{\sim}$ & $\bar{\sim}$ & $\vec{n}$ & 0 & 0 & $\stackrel{\infty}{=}$ & సి & $\cong$ & $\vec{ల}$ \\
\hline & 茯 & $\bar{\infty}$ & ల్లి & 0 & $\stackrel{\sim}{\sim}$ & 0 & 0 & 9 & 0 & 0 & $\stackrel{0}{0}$ & $a$ & I & $\mathscr{n}$ & 0 & $\stackrel{\partial}{\sim}$ \\
\hline$\dot{\overrightarrow{0}}$ & 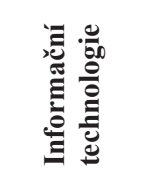 & 0 & 은 & $\theta$ & ñ & $a$ & $\mathcal{F}$ & to & 0 & $\Xi$ & 0 & 0 & $\simeq$ & 0 & $\mathscr{8}$ & $\hat{\approx}$ \\
\hline & 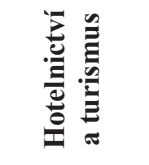 & $\mathbb{2}$ & i & $=$ & 0 & $\infty$ & $\underline{-1}$ & 0 & $r$ & 2 & $\bar{v}$ & 0 & $\exists$ & 류 & 0 & ్ָర \\
\hline & 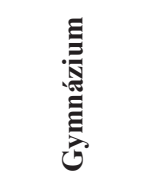 & $F$ & m & 0 & 0 & 0 & $r$ & in & 0 & n & 0 & 0 & ถิ & 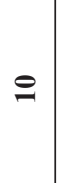 & 0 & $\stackrel{\circ}{\sim}$ \\
\hline & 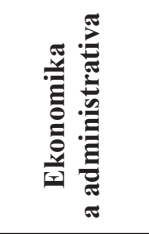 & 0 & i & 0 & $\bar{m}$ & $\tilde{N}$ & \pm & + & $\underset{ల}{\infty}$ & 0 & 0 & 고 & 0 & ల్ల & $\hat{6}$ & กิ \\
\hline & 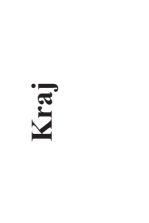 & 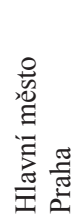 & 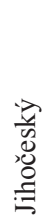 & 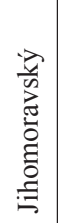 & 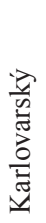 & 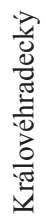 & 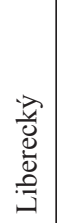 & 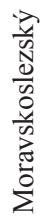 & $\begin{array}{l}\frac{\vec{y}}{0} \\
\vdots \\
0 \\
\frac{0}{0}\end{array}$ & $\begin{array}{l}\frac{2}{0} \\
0 \\
0 \\
0 \\
0 \\
0 \\
0\end{array}$ & $\begin{array}{l}\frac{2}{\sqrt[n]{n}} \\
\frac{2}{d} \\
\frac{N}{2}\end{array}$ & 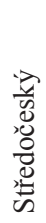 & $\begin{array}{l}\frac{2}{0} \\
\frac{0}{0} \\
.0\end{array}$ & 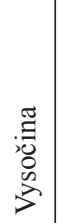 & $\begin{array}{l}\frac{\vec{v}}{\tilde{a}} \\
\stackrel{\Xi}{N}\end{array}$ & 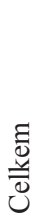 \\
\hline
\end{tabular}


opravář motorových vozidel $(8,7$ \%) (konkrétní počty respondentů jsou uvedeny v tabulce 2). V rozložení jednotlivých krajů, ze kterých respondenti pocházejí, je nejvíce zastoupeno hlavní město Praha (13,6 \%) spolu s Jihočeským krajem (13,5 \%). Naopak na opačném pólu se nachází kraj Středočeský, na který připadá pouze $1,7 \%$ probandů. Jediným krajem, ze kterého se podařilo získat data od všech studijních oborů, je kraj Jihočeský, pouze jeden obor chybí v kraji Moravskoslezském. Nejméně oborů je zastoupeno ve Středočeském kraji. Viz tabulka 2.

Posledním zjištovaným údajem je rozložení souboru z hlediska vzdělávacích obtíží. Respondenti byli dotazování, zda jim byla v minulosti diagnostikována některá z nabízených poruch, dále měli možnost vypsat jiné obtíže. V př́ípadě, že respondent věděl, že nějakými obtížemi trpěl, nevzpomněl si však na konkrétní diagnózu, mohl zvolit odpověd' „něco ano, ale nevím presně co“. Vzdělávací obtíže uvedlo 381 respondentů, což je 22,2 \% z celého výzkumného souboru. Zastoupení jednotlivých obtíží je znázorněno v tabulce 3 .

Tabulka 3 Respondenti se specifickými poruchami učení a chování $(N=381)$

\begin{tabular}{|l|c|}
\hline \multicolumn{2}{|c|}{ Počet respond. v souboru } \\
\hline dyslexie & 172 \\
\hline dysgrafie & 106 \\
\hline nevím přesně co & 93 \\
\hline porucha pozornosti & 78 \\
\hline hyperaktivita & 66 \\
\hline dyskalkulie & 39 \\
\hline dysortografie & 35 \\
\hline jiné & 11 \\
\hline
\end{tabular}

\section{Zpracování dat a výsledky}

\subsection{POLOŽKOVÁ ANALÝZA}

Data byla zpracována pomocí programu excel a SPSS. Položky 2 a 15 měly obrácenou škálu, proto byly pro účely další analýzy překódovány. Provedena byla položková analýza (tabulka 4). Popularita ${ }^{3}$ všech položek v testu se pohybovala v přijatelném rozmezí od 0,3 po 0,65 . Korelace jednotlivých položek s celkovým hrubým skórem neklesla pod hodnotu $\mathrm{r}<0,2$. V této fázi tedy nebyla vyřazena žádná z položek.

$3=\bar{\chi} / \chi_{\max }$ 


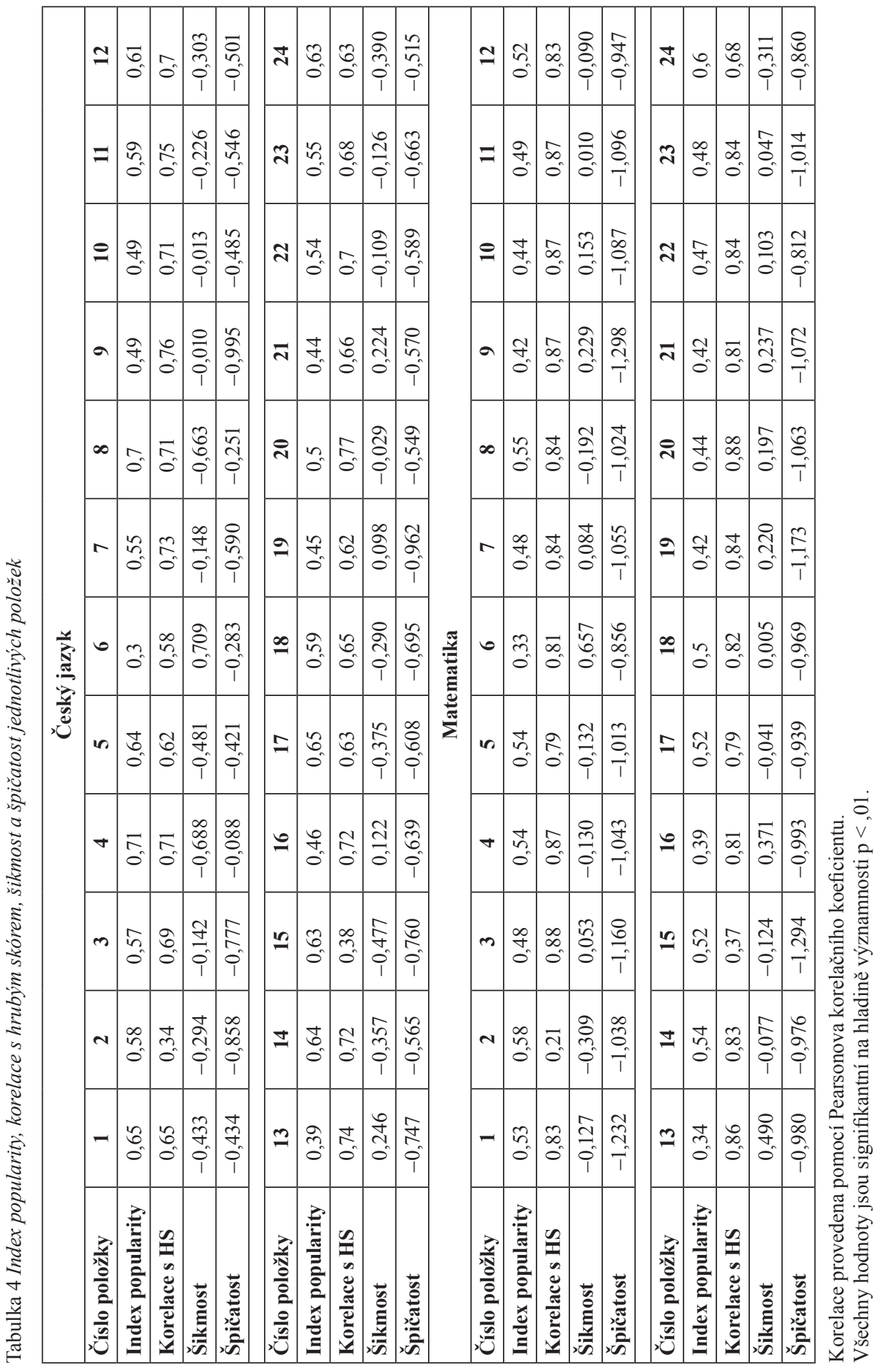




\subsection{FAKTOROVÁ ANALÝZA}

Pro poznání struktury proměnných dotazníku jsme provedli faktorovou analýzu. Nejprve byl analyzován dotazník vyplňovaný o českém jazyce. Pro posouzení vhodnosti vstupních statistických dat pro zpracování faktorovou analýzou byl použit Barlettův test sféricity, jehož nulová hypotéza ř́ká, že korelační matice je rovna jednotkové matici. $\mathrm{V}$ př́padě analyzovaného dotazníku lze tuto hypotézu zamítnout $(\mathrm{p}<, 001)$. Tomu odpovídá Kaiser-Meyer-Olkinova míra, která se pro tento dotazník rovná 0,97 , což lze považovat za naprosto dostačující. Zjiššný nízký determinant korelační matice $(\mathrm{M}=5,35 \mathrm{E}-006)$ však indikuje př́lišs silnou vzájemnou provázanost jednotlivých proměnných (naznačuje problémy s multikolinearitou).

Při extrakci faktorů pomocí metody hlavních os (Principal Axis Factoring), kdy byl zadán předpoklad dvou faktorů, vysvětloval první faktor $42,7 \%$ celkové variance a druhý pouhých $2,9 \%$. U dvou položek se objevily nízké faktorové zátěže. Jednalo se o položky 2 a 15, které byly jako jediné v dotazníku formulovány negativně (pro statistické zpracování dat byla škála obrácena). Jejich nejnižši faktorová zátěž tak může svědčit pro nepozornost respondentů, kteří si obrácené škály nepovšimli. Tyto dvě položky byly proto $v$ této fázi zpracování dat vyřazeny.

Následná analýza bez vynuceného počtu faktorů vyextrahovala čtyři faktory, opět za významného přispění prvního faktoru. Pro zjištění dalších možných významových odstínů měřeného konstruktu byla provedena rotace pomocí procedury Oblimin pro korelované faktory. Na jejím základě bylo možné rozčlenit položky do tř́ interpretovatelných faktorů (viz tabulka 5).

Tabulka 5 Faktorová matice, český jazyk $(N=1717)$

\begin{tabular}{|l|c|c|c|c|c|c|c|c|c|c|c|}
\hline Položka & $\mathbf{1}$ & $\mathbf{3}$ & $\mathbf{4}$ & $\mathbf{5}$ & $\mathbf{6}$ & $\mathbf{7}$ & $\mathbf{8}$ & $\mathbf{9}$ & $\mathbf{1 0}$ & $\mathbf{1 1}$ & $\mathbf{1 2}$ \\
\hline Faktor 1 &, 086 &,- 016 &, 133 &, 372 &,- 086 &, 374 &, 221 &,- 004 &, 111 &, 374 &, 645 \\
\hline Faktor 2 &,- 125 &,- 373 &,- 065 &,- 062 &,- 739 &,- 240 &,- 056 &,- 554 &,- 443 &,- 246 &, 009 \\
\hline Faktor 3 &,- 558 &,- 449 &,- 659 &,- 261 &, 027 &,- 212 &,- 563 &,- 334 &,- 258 &,- 236 &,- 152 \\
\hline Položka & $\mathbf{1 3}$ & $\mathbf{1 4}$ & $\mathbf{1 6}$ & $\mathbf{1 7}$ & $\mathbf{1 8}$ & $\mathbf{1 9}$ & $\mathbf{2 0}$ & $\mathbf{2 1}$ & $\mathbf{2 2}$ & $\mathbf{2 3}$ & $\mathbf{2 4}$ \\
\hline Faktor 1 &, 144 &, 439 &, 208 &, 670 &, 755 &, 001 &, 216 &, 283 &, 721 &, 474 &, 463 \\
\hline Faktor 2 &,- 627 &,- 078 &,- 526 &, 119 &,- 008 &,- 560 &,- 494 &,- 573 &,- 185 &,- 257 &,- 106 \\
\hline Faktor 3 &,- 063 &,- 300 &,- 058 &,- 143 &, 060 &,- 123 &,- 162 &, 144 &, 144 &,- 016 &,- 119 \\
\hline
\end{tabular}

Metoda extrakce: Principal Axis Factoring

Na základě analýzy obsahu jednotlivých položek lze nalézt jejich tematické propojení s ohledem na faktor, který je sytí. První faktor, sytící největší počet položek (např. Když pracuji samostatně, zvládnu si naplánovat postup tak, abych úkol včas dokončil.), se svým obsahem shoduje $\mathrm{s}$ faktorem $\mathrm{z}$ výchozího dotazníku vytvořeného $\mathrm{v}$ rámci pilotní studie, nazvaným strategie řešení problémů. Zahrnuje schopnost žáka zvolit vhodný způsob práce, naplánovat si postup, efektivně zacházet s informacemi apod. Faktor druhý obsahuje 
informace o tom, jak se respondent staví $\mathrm{k}$ náročnějším úkolům (např. $V$ tomto předmětu mám raději náročnějši úkoly, ve kterých se učím nové věci. Když pracuji samostatně, zvládnu si naplánovat postup tak, abych úkol včas dokončil.). Třetí faktor sytící pouze čtyři položky se dotýká v obecnější rovině víry respondenta ve vlastní schopnosti (např. Dokážu porozumét tomu, co se v tomto předmětu učíme.).

$\mathrm{S}$ ohledem na nízké Eigenvalue u druhého a třetího vyextrahovaného faktoru (což dokládá rozložení zátěží ve faktorové matici) je podle našeho názoru přijatelné jednofaktorové řešení. Tomu odpovídají i nízké hodnoty determinantu korelace. Přikláníme se tedy k použití dotazníku jako jednodimenzionálního.

$\mathrm{V}$ př́padě dotazníku vyplňovaného pro matematiku lze stejně jako $\mathrm{v}$ předchozím př́ípadě zamítnout nulovou hypotézu Barlettova testu sféricity $(\mathrm{p}<, 001)$, Kaiser-Meyer-Olkinova míra je dostačující $(0,984)$, determinant korelační matice $(\mathrm{M}=3,387 \mathrm{E}-11)$ je však i v tomto př́padě př́lišs nízký. Opět nejnižší faktorovou zátěž nesou položky 2 a 15 , které byly i v tomto prípadě vyřazeny. Po jejich odstranění byl vyextrahován pouze jediný faktor vysvětlující $68,6 \%$ celkové variance. Rozdíl mezi výsledky faktorové analýzy v př́padě českého jazyka a matematiky je možné vysvětlit tím, že dotazník o matematice vyplňovali žáci jako druhý, tedy lze předpokládat, že mu již nevěnovali takovou pozornost a uchylovali se k méně pozornému vyplňování a zjednodušujícím odpovědím.

\subsection{RELIABILITA}

Reliabilita byla testována zvlášt’ pro dotazník vyplněný o českém jazyce a o matematice. Vnitřní konzistence dotazníků odhadovaná pomocí Cronbachova alfa dosahuje pro český jazyk hodnoty $\alpha=0,948$ a pro matematiku $\alpha=0,979$. Hodnoty ukazují, že vytvořený dotazník je jak $\mathrm{v}$ případě českého jazyka, tak $\mathrm{v}$ př́ípadě matematiky vnitřně konzistentní. Vysoká reliabilita však není v rozporu s vnitřním členěním škály na subdimenze. Guttmanův split-half koeficient je pro český jazyk $r=0,925$ a pro matematiku $r=0,969$. Ve všech př́padech se tedy jedná o hodnoty dostatečně vysoké, výzkumný nástroj tedy lze považovat za reliabilní.

\subsection{VALIDITA}

Validita výzkumného nástroje byla zjišstována pomocí čtyř kritérií: souvislost naměřené VAÚ se školní známkou z daného předmětu, souvislost VAÚ s hodnocením úspěšnosti zvládnutí náročné školní situace $\mathrm{v}$ daném předmětu, porovnání VAỨ s prožitky spojenými s náročnou školní situací a zařazeno bylo i vnější kritérium, kdy VAÚ hodnotili u svých žáků učitelé.

První kritérium validity vychází z poznatků mnoha studií (např. Altunsoy et al., 2010; Caprara et al., 2008; Diseth, 2011), že žáci s vyšší VAUU podávají lepší studijní výkony, které se odrážejí v lepším hodnocení. VAỨ ovlivňuje studijní výkony díky svému působení na kognitivní, motivační, afektivní a selektivní procesy jedince (Bandura, 1997). V našem souboru bylo provedeno porovnání jednak s aktuální známkou (která žákủm vycházela $v$ době měření), jednak se známkou, kterou měli z daného předmětu na posledním vysvědčení. $V$ tabulce 6 vidíme statisticky významnou středně silnou negativní korelaci mezi hrubými skóry naměřenými v českém jazyce (HS Čj) a známkou z českého jazyka i mezi hrubými skóry naměřenými v matematice (HS M) a známkou z matematiky. 
Vyšší VAÚ je tedy spojena s nižšími (tedy lepšími) školními známkami, přičemž o něco těsnější je souvislost s aktuální známkou.

Tabulka 6 Korelace vnimané akademické účinnosti se školní známkou

\begin{tabular}{|c|c|c|c|c|c|}
\hline \multicolumn{6}{|c|}{ Spearmanova korelace } \\
\hline \multicolumn{2}{|c|}{ Známky - český jazyk } & HS Čj & \multicolumn{2}{|c|}{ Známky - matematika } & HS M \\
\hline \multirow{3}{*}{ aktuální známka } & korelace &,$- 461 * *$ & \multirow{3}{*}{ aktuální známka } & korelace &,$- 598^{* *}$ \\
\hline & sig. & ,000 & & sig. & ,000 \\
\hline & $\mathrm{N}$ & 1599 & & $\mathrm{~N}$ & 1562 \\
\hline \multirow{3}{*}{$\begin{array}{l}\text { známka } \\
\text { na posledním } \\
\text { vysvědčení }\end{array}$} & korelace &,$- 405 * *$ & \multirow{3}{*}{$\begin{array}{l}\text { známka } \\
\text { na posledním } \\
\text { vysvědčení }\end{array}$} & korelace &,$- 500^{* *}$ \\
\hline & sig. & ,000 & & sig. &, 000 \\
\hline & $\mathrm{N}$ & 1374 & & $\mathrm{~N}$ & 1343 \\
\hline
\end{tabular}

** statistická významnost $\mathrm{p}<, 001$

V každém předmětu byly dále prezentovány čtyři náročné školní situace (které vzešly z pilotní studie). Žáci byli dotazováni, na kolik procent si myslí, že tuto situaci zvládnou. Výsledná procenta byla porovnávána s naměřenou VAÚ. Tato souvislost slouží jako druhé kritérium pro zjištění validity výzkumného nástroje. Předpokládáme, že žáci s vyšší VAÚ si více věří ve zvládnutí náročných situací a naopak. Vycházíme z předchozích zjištění, že žáci s nízkou VAÚ častěji pochybují o svých schopnostech vyřrešit zadaný úkol (např. Williams, Williams, 2010; Zimmerman, Bandura, 1994). V tabulce 7 vidíme, že i tento předpoklad byl naplněn. Všechny modelové situace v obou předmětech vykazovaly pozitivní vzájemnou souvislost s naměřenou VAÚ na hladině významnosti $\mathrm{p}<, 001$.

Tabulka 7 Korelace vnímané akademické účinnosti s hodnocením úspěšnosti v náročné školní situaci

\begin{tabular}{|c|c|c|c|c|c|}
\hline \multicolumn{6}{|c|}{ Spearmanova korelace } \\
\hline \multicolumn{2}{|l|}{ Náročné situace - český jazyk } & \multirow{2}{*}{$\frac{\text { HS Čj }}{, 537^{* *}}$} & \multicolumn{2}{|l|}{ Náročné situace - matematika } & \multirow{2}{*}{$\begin{array}{c}\text { HS M } \\
, 715^{* *}\end{array}$} \\
\hline \multirow{3}{*}{$\begin{array}{l}\text { 1. Máte za úkol napsat } \\
\text { seminární práci. Nejedná } \\
\text { se však o pouhý popis, ale } \\
\text { o srovnání dvou souvisejících } \\
\text { témat. }\end{array}$} & korelace & & \multirow{3}{*}{$\begin{array}{l}\text { 1. V rámci procvičování } \\
\text { nového učiva si vás vyučující } \\
\text { vzal k tabuli, abyste před } \\
\text { třídou vypočítal(a) zadaný } \\
\text { příklad. }\end{array}$} & korelace & \\
\hline & sig. &, 000 & & sig. &, 000 \\
\hline & $\mathrm{N}$ & 1706 & & $\mathrm{~N}$ & 1706 \\
\hline \multirow{3}{*}{$\begin{array}{l}\text { 2. Čeká vás referát před } \\
\text { třídou. Musíte k němu mít } \\
\text { připravenou prezentaci } \\
\text { a mluvit spatra. }\end{array}$} & korelace &, $360^{* *}$ & \multirow{3}{*}{$\begin{array}{l}\text { 2. Učitel vás neplánovaně } \\
\text { vyvolal ke zkoušení u tabule. }\end{array}$} & korelace &, $704^{* *}$ \\
\hline & sig. &, 000 & & sig. & ,000 \\
\hline & $\mathrm{N}$ & 1698 & & $\mathrm{~N}$ & 1698 \\
\hline \multirow{3}{*}{$\begin{array}{l}\text { 3. Připravujete se na náročné } \\
\text { ústní zkoušení, které má } \\
\text { rozhodnout o vaší výsledné } \\
\text { známce na vysvědčení. }\end{array}$} & korelace &, $451^{* *}$ & \multirow{3}{*}{$\begin{array}{l}\text { 3. Připravujete se na náročné } \\
\text { ústní zkoušení, které má } \\
\text { rozhodnout o vaší výsledné } \\
\text { známce na vysvědčení. }\end{array}$} & korelace & $653^{* *}$ \\
\hline & sig. &, 000 & & sig. & ,000 \\
\hline & $\mathrm{N}$ & 1695 & & $\mathrm{~N}$ & 1695 \\
\hline \multirow{3}{*}{$\begin{array}{l}\text { 4. Připravujete se na pololetní } \\
\text { písemnou práci. }\end{array}$} & korelace &, $519^{* *}$ & \multirow{3}{*}{$\begin{array}{l}\text { 4. Připravujete se na pololetní } \\
\text { písemnou práci. }\end{array}$} & korelace & $675^{* *}$ \\
\hline & sig. &, 000 & & sig. &, 000 \\
\hline & $\mathrm{N}$ & 1687 & & $\mathrm{~N}$ & 1687 \\
\hline
\end{tabular}

** statistická významnost $\mathrm{p}<, 001$ 
U každé ze čtyř výše zmíněných náročných situací bylo prezentováno osm prožitků (čtyři laděné pozitivně, čtyři negativně). ${ }^{4} \mathrm{Zde}$ jsme vycházeli z předešlých poznatků (např. Huerta et al., 2017; Roick, Ringeisen, 2017; Zimmerman, Bandura, 1994) o souvislosti vnímané osobní účinnosti s prožívanými emocemi (vyšší vnímaná účinnost je propojena s pozitivnějším prožíváním situace). Po ověření reliability škály prožitků ${ }^{5}$ jsme vytvořili pro každou situaci hrubé skóry pozitivních a negativních prožitků. Dále jsme zjišt'ovali souvislost s naměřenou VAÚ v jednotlivých situacích a předmětech. Výsledky znázorněné v tabulce 8 ukazují statisticky signifikantní korelaci $(\mathrm{p}<, 001)$ prožitků a naměřené VAÚ ve všech modelových situacích (v případě pozitivních prožitků se jedná o pozitivní vzájemnou závislost, v př́padě negativních prožitků o negativní vzájemnou závislost).

Posledním kritériem bylo hodnocení VAỨ žáka učitelem. Učitel vyplňoval o žácích ze své třídy stejný dotazník, jako vyplňovali žáci. Byl požádán, aby si představil, jak by na předkládané otázky reagovali konkrétní žáci. Mohli jsme tedy porovnat hodnocení žáka samotného a hodnocení žáka učitelem. Vzhledem k časové vytíženosti učitelů bylo vyplněno pouze 33 dotazníků o VAÚ v českém jazyce (třemi různými učiteli) a 12 v matematice (jeden učitel). Kvůli nízkému počtu vyplněných dotazníků z matematiky jsme přistoupili pouze $\mathrm{k}$ analýze dotazníků z českého jazyka. Použitím Wilcoxonova párového testu bylo zjišt'ováno, zda se objevuje statisticky významný rozdíl mezi hodnocením VAÚ podle žáků samotných a podle jejich učitelů, který se neprokázal $(\mathrm{W}=-1,599, \mathrm{p}=, 110)$.

Všechna zvolená kritéria byla splněna, na jejich základě lze vytvořený výzkumný nástroj považovat za validní pro měření VAÚ.

\subsection{ROZDÍL MEZI VNÍMANOU AKADEMICKOU ÚČINNOSTÍ V ČESKÉM JAZYCE A V MATEMATICE}

VAÚ byla měřena stejným nástrojem zvlášt' pro český jazyk a pro matematiku. Výsledné hrubé skóry obou předmětů byly porovnány v rámci celého datového souboru $(\mathrm{N}=1717)$ párovým $\mathrm{t}$-testem. Dle výsledků testu $(\mathrm{t}=11,107, \mathrm{p}<, 001)$ se objevuje statisticky významný rozdíl mezi hrubými skóry dosaženými v českém jazyce a v matematice. Průměrný hrubý skór vychází nižší v matematice $(\mathrm{M}=74,3, \mathrm{SD}=29,4)$, než v českém jazyce $(M=82,7, S D=20,3)$. Ve výzkumném souboru jako celku tak dosahují respondenti vyšší VAÚ v českém jazyce, než v matematice.

Současně byla zjišt’ována vzájemná korelace mezi těmito dvěma proměnnými. Na hladině významnosti $\mathrm{p}<, 001$ se objevuje slabá pozitivní vzájemná souvislost (Pearsonův $\mathrm{r}=$,243) mezi VAÚ v českém jazyce a v matematice. Se zvyšováním VAÚ v jednom předmětu dochází ke zvyšování VAỨ i v předmětu druhém. Detailnější pohled přinesla analýza zaměřená na jednotlivé typy škol, kdy se statisticky významná vzájemná korelace proměnných ukazuje u SOU (Pearsonův $\mathrm{r}=, 338 ; \mathrm{p}<, 001$ ) a SOŠ (Pearsonův $\mathrm{r}=, 120, \mathrm{p}<, 001$ ), nikoli však u gymnázií (Pearsonův $\mathrm{r}=, 041, \mathrm{p}=, 495)$. V rámci gymnázií tedy existuje statisticky významný rozdíl mezi průměrnými hrubými skóry v českém jazyce a matematice, tyto dvě proměnné však spolu, na rozdíl od zbývajících typů škol, nekorelují.

\footnotetext{
4 Pozitivní prožitky: baví mě to, zajímá mě to, je to adrenalin, cítím jistotu, je to výzva. Negativní prožitky: mám strach, jsem nervózní, jsem zoufalý, jsem naštvaný, cítím stres.

5 Reliabilita prožitků byla ověřena faktorovou analýzou, která potvrdila dva faktory: pozitivní a negativní prožitky.
} 
Tabulka 8 Korelace vnimané akademické účinnosti s prožitky

\begin{tabular}{|c|c|c|c|c|c|c|c|}
\hline \multicolumn{8}{|c|}{ Spearmanova korelace } \\
\hline \multicolumn{3}{|c|}{ Prožitky - český jazyk } & HS Čj & \multicolumn{3}{|c|}{ Prožitky - matematika } & HS M \\
\hline \multirow{6}{*}{$\begin{array}{l}1 . \\
\text { seminární } \\
\text { práce }\end{array}$} & \multirow{3}{*}{ pozit. } & korel. &, $418^{* *}$ & \multirow{6}{*}{$\begin{array}{l}1 . \\
\text { nová } \\
\text { látka }\end{array}$} & \multirow{3}{*}{ pozit. } & korel. &, $551^{* *}$ \\
\hline & & sig. &, 000 & & & sig. &, 000 \\
\hline & & $\mathrm{N}$ & 1696 & & & $\mathrm{~N}$ & 1695 \\
\hline & \multirow{3}{*}{ negat. } & korel. &,$- 240^{* *}$ & & \multirow{3}{*}{ negat. } & korel. &,$- 429^{* *}$ \\
\hline & & sig. &, 000 & & & sig. &, 000 \\
\hline & & $\mathrm{N}$ & 1698 & & & $\mathrm{~N}$ & 1690 \\
\hline \multirow{6}{*}{$\begin{array}{l}2 . \\
\text { referát } \\
\text { před třídou }\end{array}$} & \multirow{3}{*}{ pozit. } & korel. &, $293^{* *}$ & \multirow{6}{*}{$\begin{array}{l}2 . \\
\text { neplánované } \\
\text { zkoušení }\end{array}$} & \multirow{3}{*}{ pozit. } & korel. &, $433^{* *}$ \\
\hline & & sig. &, 000 & & & sig. &, 000 \\
\hline & & $\mathrm{N}$ & 1693 & & & $\mathrm{~N}$ & 1695 \\
\hline & \multirow{3}{*}{ negat. } & korel. &,$- 172^{* *}$ & & \multirow{3}{*}{ negat. } & korel. &,$- 362^{* *}$ \\
\hline & & sig. &, 000 & & & sig. &, 000 \\
\hline & & $\mathrm{N}$ & 1694 & & & $\mathrm{~N}$ & 1692 \\
\hline \multirow{6}{*}{$\begin{array}{l}3 . \\
\text { ústní } \\
\text { zkoušení }\end{array}$} & \multirow{3}{*}{ pozit. } & korel. &, $244^{* *}$ & \multirow{6}{*}{$\begin{array}{l}3 . \\
\text { ústní } \\
\text { zkoušení }\end{array}$} & \multirow{3}{*}{ pozit. } & korel. &, $399^{* *}$ \\
\hline & & sig. &, 000 & & & sig. & 000 \\
\hline & & $\mathrm{N}$ & 1689 & & & $\mathrm{~N}$ & 1690 \\
\hline & \multirow{3}{*}{ negat. } & korel. &,$- 177^{* *}$ & & \multirow{3}{*}{ negat. } & korel. &,$- 370^{* *}$ \\
\hline & & sig. & ,000 & & & sig. & ,000 \\
\hline & & $\mathrm{N}$ & 1692 & & & $\mathrm{~N}$ & 1689 \\
\hline \multirow{6}{*}{$\begin{array}{l}4 . \\
\text { pololetní } \\
\text { práce }\end{array}$} & \multirow{3}{*}{ pozit. } & korel. &, $281^{* *}$ & \multirow{6}{*}{$\begin{array}{l}4 . \\
\text { pololetní } \\
\text { práce }\end{array}$} & \multirow{3}{*}{ pozit. } & korel. &, $405^{* *}$ \\
\hline & & sig. &, 000 & & & sig. &, 000 \\
\hline & & $\mathrm{N}$ & 1696 & & & $\mathrm{~N}$ & 1694 \\
\hline & \multirow{3}{*}{ negat. } & korel. &,$- 189^{* *}$ & & \multirow{3}{*}{ negat. } & korel. &,$- 356^{* *}$ \\
\hline & & sig. &, 000 & & & sig. &, 000 \\
\hline & & $\mathrm{N}$ & 1694 & & & $\mathrm{~N}$ & 1688 \\
\hline
\end{tabular}

** statistická významnost $\mathrm{p}<, 001$

\subsection{SOUVISLOSTI VNÍMANÉ AKADEMICKÉ ÚČINNOSTI S DALŠÍMI PROMĚNNÝMI}

Mimo údaje k ověření validity dotazníku byly sledovány další proměnné, které mohou s VAÚ souviset. Jedná se o pohlaví respondenta, jeho věk, typ studované školy (SOU, SOŠ, gymnázium), přítomnost specifických poruch učení a chování, školní známku, oblibu předmětu, způsob výuky a zajímavost obsahu předmětu. ${ }^{6}$

Rozdíl mezi naměřenými hrubými skóry v závislosti na pohlaví jsme testovali pomocí dvouvýběrového t-testu. Na základě Leveneova testu nebyl ani v př́ipadě českého jazyka

\footnotetext{
6 Položky zjišt’ující tyto proměnné (škálováno od 4 do 1 , kde 4 znamená oblíbenost, vyhovující výuka, zájem):

Tento predmèt patři mezi mé: oblibené - spišse oblibené - spišse neoblibené-neoblibené

Způsob výuky tohoto předmétu mi: vyhovuje - spiše vyhovuje - spiše nevyhovuje - nevyhovuje

Obsah tohoto predmètu je pro mé: zajímavý - spiše zajímavý - spiše nezajímavý - nezajímavý
} 
ani matematiky zjištěn statisticky významný rozdíl v rozptylech hrubých skórů. Signifikantní rozdíl mezi naměřenou VAÚ dívek a chlapců se objevuje v obou předmětech $(\mathrm{N}=1711$; český jazyk $\mathrm{t}=2,027, \mathrm{p}<, 05$; matematika $\mathrm{t}=-6,590, \mathrm{p}<, 001)$. Podíváme-li se na průměrné hrubé skóry, vidíme, že v českém jazyce dosahovaly vyšších výsledků dívky ( $\varnothing \mathrm{HS}=83,62)$ než chlapci ( $\varnothing \mathrm{HS}=81,62)$. V matematice pak naopak lépe skórovali chlapci (ø HS = 79,26) než dívky (ø HS = 69,99).

Vzájemná závislost VAÚ a věku respondentů byla zjišt’ována pomocí Spearmanova korelačního koeficientu a neukázala se jako signifikantní ani pro jeden z předmětů $(\mathrm{N}=1594$; český jazyk $\mathrm{r}=-, 028, \mathrm{p}=, 258$; matematika $\mathrm{r}=-, 049, \mathrm{p}=, 050)$.

Rozdíl mezi naměřenou VAÚ v závislosti na typu studované školy jsme testovali pomocí analýzy rozptylu (ANOVA). Byl zjištěn statisticky významný rozdíl u obou předmětů na hladině významnosti $\mathrm{p}<, 001$ (český jazyk $\mathrm{F}=51,302$; matematika $\mathrm{F}=22,408$ ). V tabulce 9 jsou zaznamenány průměrné hrubé skóry v závislosti na typu studované školy. V obou prrípadech se nejnižší průměrný hrubý skór objevuje u SOU a nejvyšší průměrný hrubý skór u gymnázií.

Tabulka 9 Prưměrné hrubé skóry v závislosti na typu studované školy

\begin{tabular}{|l|l|c|c|}
\hline \multicolumn{4}{|c|}{ Průměrné HS dle typu školy } \\
\hline \multicolumn{2}{|c|}{ Typ školy } & HS Čj & HS M \\
\hline SOU & průměr & 79,22 & 71,51 \\
\hline & N & 690 & 690 \\
\hline SOŠ & směr.od. & 20,217 & 28,214 \\
\hline & průměr & 81,96 & 72,92 \\
\hline & N & 751 & 751 \\
\hline gymnázia & směr.od. & 19,426 & 29,567 \\
\hline & průměr & 93,33 & 84,88 \\
\hline & N & 276 & 276 \\
\hline & směr.od. & 19,363 & 29,420 \\
\hline
\end{tabular}

Pomocí dvouvýběrového t-testu jsme dále testovali rozdíl mezi naměřenými hrubými skóry v závislosti na přítomnosti specifických poruch učení a chování. Rozdíl vyšel signifikantní v obou předmětech $(\mathrm{N}=1717$; český jazyk $\mathrm{t}=6,160, \mathrm{p}<, 001$; matematika $\mathrm{t}=2,050, \mathrm{p}<, 05)$. V př́padě výskytu obtíží tedy dochází ke snížení naměřené VAÚ jak v českém jazyce (ø HS bez obtíží = 84,3; ø HS s obtížemi $=77,1)$, tak v matematice (ø HS bez obtíží $=75,1$; ø HS s obtížemi $=71,6)$.

Vzájemná propojenost školní známky s naměřenou VAÚ se potvrdila již při testování validity nástroje. Tabulka 10 ukazuje rozložení průměrných hrubých skórů v závislosti na školní známce, která respondentům vycházela aktuálně v době měření.

U proměnných obliba předmětu, způsob výuky, zajímavost obsahu předmětu jsme zjišt'ovali vzájemnou korelaci s hrubými skóry pomocí Spearmanova korelačního koeficientu. Všechny tři proměnné vykazují pozitivní vzájemnou závislost s naměřenou VAÚ v obou předmětech na hladině významnosti $\mathrm{p}<, 001$ (český jazyk: $\mathrm{N}=1700$, obliba $\mathrm{r}=, 507$, obsah $\mathrm{r}=, 445$, způsob výuky $\mathrm{r}=, 303$; matematika: $\mathrm{N}=1665$, obliba $\mathrm{r}=, 750$, 
Tabulka 10 Průměrné hrubé skóry v závislosti na školní známce

\begin{tabular}{|l|l|c|c|}
\hline \multicolumn{2}{|c|}{ Aktuální známka } & HS Čj & HS M \\
\hline 1 & průměr & 102,81 & 107,75 \\
\hline & N & 134 & 183 \\
\hline & směr. od. & 19,076 & 22,159 \\
\hline 2 & průměr & 89,73 & 88,68 \\
\hline & N & 534 & 415 \\
\hline & směr. od. & 17,773 & 24,626 \\
\hline 3 & průměr & 78,36 & 68,54 \\
\hline & N & 626 & 496 \\
\hline & směr. od. & 17,422 & 24,167 \\
\hline 4 & průměr & 69,82 & 55,28 \\
\hline & N & 286 & 400 \\
\hline & směr. od. & 18,014 & 21,466 \\
\hline 5 & průměr & 64,42 & 46,18 \\
\hline & N & 19 & 68 \\
\hline & směr. od. & 26,389 & 23,771 \\
\hline
\end{tabular}

obsah $\mathrm{r}=, 676$, způsob výuky $r=, 486$ ). Se stoupající VAÚ tedy stoupá i obliba předmětu, zajímavost obsahu a spokojenost se způsobem výuky předmětu.

Pro porovnání vlivu jednotlivých proměnných na VAÚ jsme zvolili metodu regresní analýzy. Pomocí mnohonásobné lineární regrese 7 jsme zjistili, že statisticky významný vliv na VAÚ naměřenou v českém jazyce má pohlaví respondenta, typ studované školy (kódovány jako dvě dummy proměnné s referenční kategorií SOŠ), přítomnost specifických poruch učení a chování (binární proměnná), školní známka (jak aktuální, tak na posledním vysvědčení), obliba předmětu a zajímavost obsahu předmětu (viz tab. 11). Nejsilnější vliv se ukazuje u obliby předmětu $(\beta=, 273)$, aktuální známky $(\beta=-, 210)$ a zajímavosti obsahu předmětu $(\beta=, 138)$. Jako statisticky nevýznamný se ukázal vliv věku respondentů a způsobu výuky daného předmětu. Vysvětlená variance závisle proměnné je $39 \%\left(R^{2}=, 387\right)$. Viz Tabulka 11 .

Stejná metoda použitá pro naměřenou VAÚ v matematice prokázala statisticky významný vliv proměnné pohlaví, školní známka (aktuální i na posledním vysvědčení), obliba předmětu a zajímavost obsahu předmětu (viz tab. 12). Nejsilnější vliv se ukazuje u stejných proměnných jako v př́ípadě VAÚ v českém jazyce: obliba předmětu $(\beta=, 482)$, aktuální známka $(\beta=-, 183)$ a zajímavost obsahu predmětu $(\beta=, 151)$. Jako statisticky nevýznamný se v př́ípadě VAÚ v matematice ukázal rovněž vliv věku respondentů a způsobu výuky předmětu, navíc však také typ studované školy a přítomnost specifických poruch učení a chování. Vysvětlená variance závisle proměnné je $62 \%\left(\mathrm{R}^{2}=, 624\right)$.

\footnotetext{
7 Předpoklady pro použití metody lineární regrese jsou pro naše data splněny: závisle proměnné jsou metrické, nezávisle proměnné jsou intervalové nebo dichotomické (proměnná typ školy byla převedena na dummy proměnné), dle ukazatelů VIF a tolerance (tab. 11 a 12) mezi sebou nejsou nezávisle proměnné vysoce korelovány, vzhledem k velikosti souboru můžeme předpokládat normální rozložení).
} 


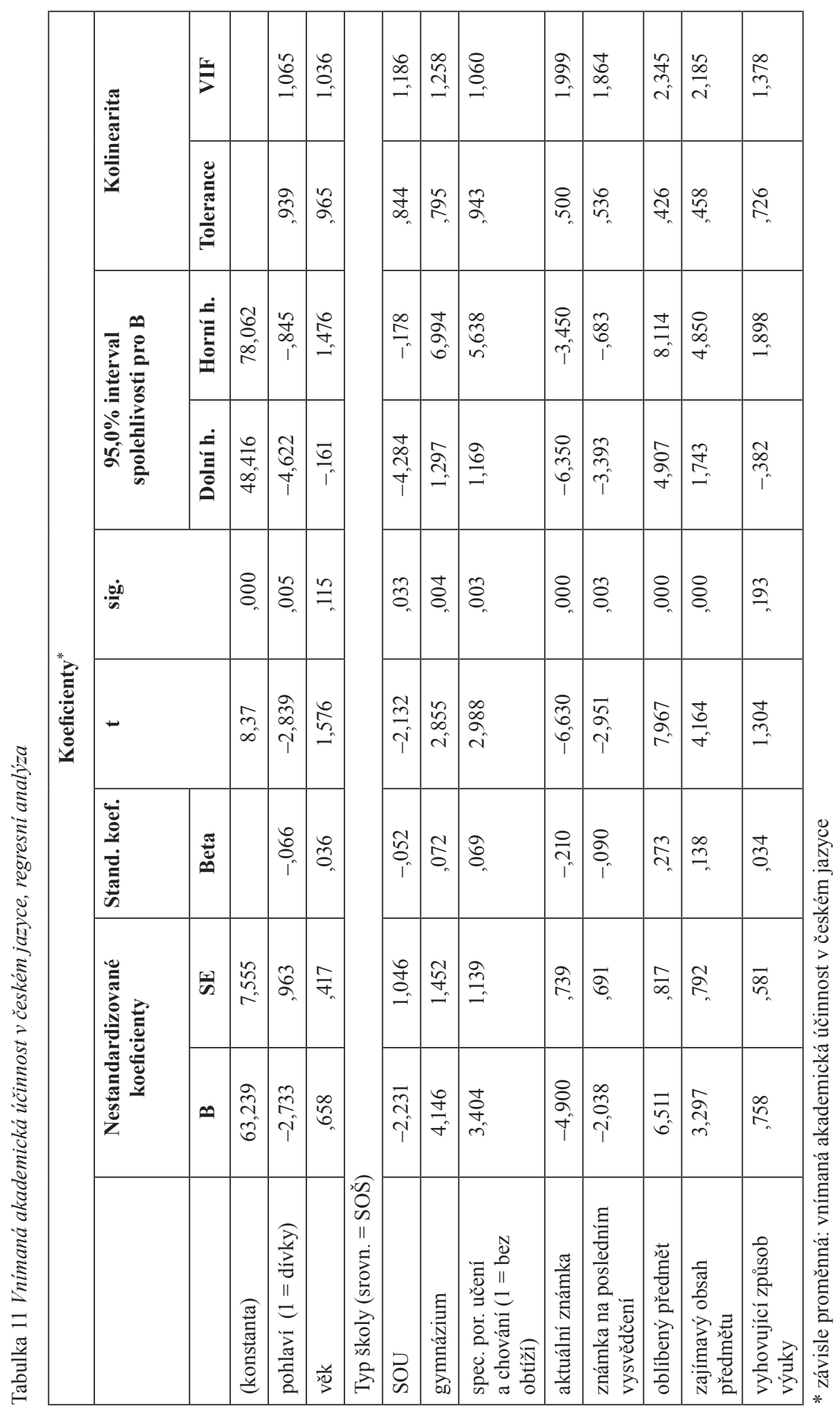




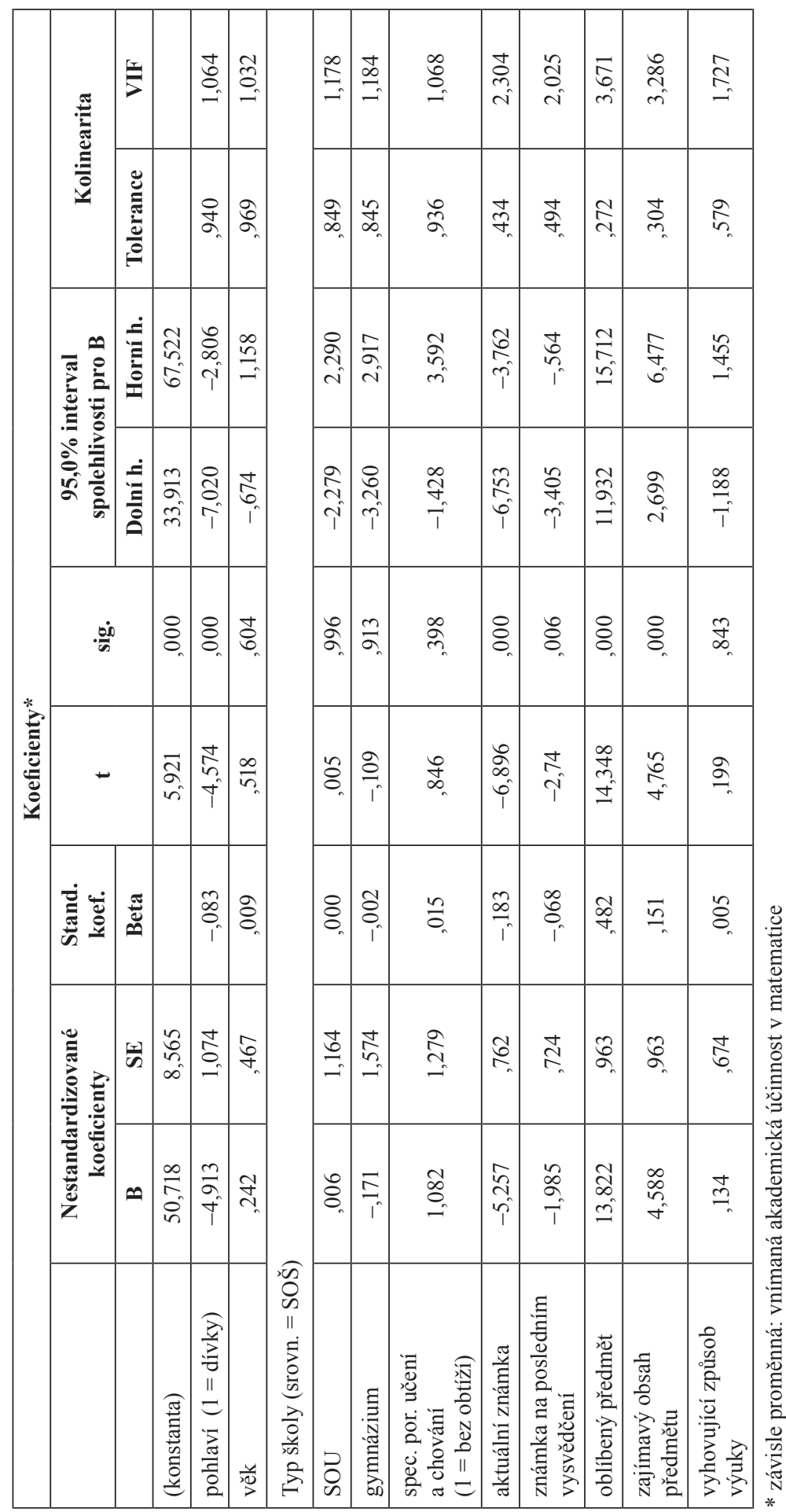


Jako zásadní prediktory se $\mathrm{v}$ př́ípadě českého jazyka i matematiky ukázaly proměnné obliba předmětu, aktuální školní známka a zajímavost obsahu předmětu. Respondenti s vyšší VAÚ tedy častěji hodnotili daný předmět jako jejich oblíbený, jehož obsah jim připadá zajímavý. Vyšší VAÚ zároveň souvisí s lepší školní známkou.

U obou předmětů vyšel v regresi signifikantní vliv také v př́ípadě proměnné pohlaví. Jak již bylo uvedeno, dle porovnání hrubých skórů dosahují v českém jazyce vyšších výsledků dívky, v matematice naopak lépe skórují chlapci. Podle výsledků regrese však vidíme, že když kontrolujeme vliv dalších proměnných, snižuje ženské pohlaví VAÚ v českém jazyce, i v matematice (vliv pohlaví je však v porovnání s dalšími zařazenými prediktory velmi slabý).

Proměnná typ studované školy se $v$ prrípadě regrese ukázala jako signifikantní prediktor VAÚ v českém jazyce, nikoli však u matematiky. Z výše uvedeného textu je patrné, že v př́ípadě, kdy nebyl kontrolován vliv dalších proměnných, byl zjištěn statisticky významný rozdíl pro oba předměty. $\mathrm{K}$ podobnému závěru docházíme i v př́padě specifických poruch učení a chování, kdy prosté porovnání hrubých skórů přináší statisticky významný rozdíl u obou předmětů, v prŕípadě regrese se však ukázal signifikantní vliv této proměnné pouze u českého jazyka.

Proměnná věk a způsob výuky předmětu se v rámci regrese ukázaly jako nevýznamné prediktory VAÚ. V př́padě věku nebyla zjištěna ani signifikantní korelace s hrubými skóry. Proměnná způsob výuky sice vykazuje pozitivní vzájemnou závislost s hrubými skóry, v modelu regresní analýzy se však tento vliv nepotvrdil. Vzájemné korelace jednotlivých proměnných jsou pro ilustraci uvedeny v tabulce 13 a 14 .

Tabulka 13 Korelace proměnných z regresní analýzy - český jazyk $(N=1233)$

\begin{tabular}{|c|c|c|c|c|c|c|c|c|c|c|}
\hline \multicolumn{11}{|c|}{ Pearsonova korelace } \\
\hline & 1 & 2 & 3 & 4 & 5 & 6 & 7 & 8 & 9 & 10 \\
\hline (1) HS Čj & 1 & & & & & & & & & \\
\hline (2) pohlaví &, 015 & 1 & & & & & & & & \\
\hline (3) věk &,- 035 &,- 026 & 1 & & & & & & & \\
\hline $\begin{array}{l}\text { (4) typ školy } \\
- \text { SOU }\end{array}$ &,$- 172^{* * *}$ &, $099^{* * *}$ &, $104^{* * *}$ & 1 & & & & & & \\
\hline $\begin{array}{l}\text { (5) typ školy } \\
\text { - gymn. }\end{array}$ &, $278^{* * *}$ &, 014 &,$- 135^{* * *}$ &,$- 317^{* * *}$ & 1 & & & & & \\
\hline (6) specif. poruchy &, $15^{* * *}$ &, $089^{* *}$ &,$- 061^{*}$ &,$- 178^{* * *}$ &, $113^{* * *}$ & 1 & & & & \\
\hline $\begin{array}{l}\text { (7) aktuální } \\
\text { známka }\end{array}$ &,$- 47^{* * *}$ &,$- 102^{* * *}$ &, $114^{* * *}$ &, $203^{* * *}$ &,$- 33^{* * *}$ &,$- 144^{* * *}$ & 1 & & & \\
\hline $\begin{array}{l}\text { (8) známka } \\
\text { vysvědčení }\end{array}$ &,$- 396^{* * *}$ &,$- 105^{* * *}$ &, $146^{* * *}$ &, $13^{* * *}$ &,$- 321^{* * * *}$ &,$- 134^{* * *}$ &, $663^{* * *}$ & 1 & & \\
\hline (9) obliba předmětu &, $525^{* * *}$ &, $097^{* * *}$ &,- 044 &,$- 083^{* *}$ &, $225^{* * *}$ &, $075^{* *}$ &,$- 415^{* * *}$ &,$- 351^{* * *}$ & 1 & \\
\hline $\begin{array}{l}\text { (10) zajímavost } \\
\text { obsahu }\end{array}$ &, $449^{* * *}$ &, $159^{* * *}$ &,- 03 &,- 043 &, $177^{* * *}$ &, $051^{*}$ &,$- 324^{* * *}$ &,$- 273^{* * *}$ &, $715^{* * *}$ & 1 \\
\hline (11) způsob výuky &, $306^{* * *}$ & ,012 &,- 014 & 023 &, $098^{* * *}$ & ,046 &,$- 25^{* * *}$ &,$- 18^{* * *}$ &, $477^{* * *}$ &, $468^{* * *}$ \\
\hline
\end{tabular}

$* \mathrm{p}<, 05, * * \mathrm{p}<, 01, * * * \mathrm{p}<, 001$ 
Tabulka 14 Korelace proměnných z regresni analýzy - matematika $(N=1236)$

\begin{tabular}{|l|l|l|l|l|l|l|l|l|l|l|}
\hline \multicolumn{7}{|c|}{ Pearsonova korelace } \\
\hline & 1 & 2 & 3 & 4 & 5 & 6 & 7 & 8 & 9 & 10 \\
\hline (1) HS M & 1 & & & & & & & & & \\
\hline (2) pohlaví &,$- 167^{* * *}$ & 1 & & & & & & & & \\
\hline (3) věk &,- 035 &,- 023 & 1 & & & & & & & \\
\hline (4) typ školy - SOU &,$- 089^{* * *}$ &, $098^{* * *}$ &, $108^{* * *}$ & 1 & & & & & & \\
\hline (5) typ školy - gymn. &, $145^{* * *}$ &, 012 &,$- 136^{* * *}$ &,$- 317^{* * *}$ & 1 & & & & & \\
\hline (6) specif. poruchy &, $057^{*}$ &, $084^{* *}$ &,$- 066^{*}$ &,$- 19^{* * *}$ &, $111^{* * *}$ & 1 & & & & \\
\hline (7) aktuální známka &,$- 581^{* * *}$ &, 002 &, $1^{* * *}$ &, $102^{* * *}$ &,$- 24^{* * *}$ &,$- 121^{* * *}$ & 1 & & & \\
\hline $\begin{array}{l}\text { (8) známka } \\
\text { vysvědčení }\end{array}$ &,$- 499^{* * *}$ &,- 021 &, $078^{* *}$ &, $121^{* * *}$ &,$- 195^{* * *}$ &,$- 118^{* * *}$ &, $694^{* * *}$ & 1 & & \\
\hline (9) obliba předmětu &, $758^{* * *}$ &,$- 15^{* * *}$ &,- 032 &,$- 092^{* *}$ &, $144^{* * *}$ &, 029 &,$- 567^{* * *}$ &,$- 501^{* * *}$ & 1 & \\
\hline $\begin{array}{l}\text { (10) zajímavost } \\
\text { obsahu }\end{array}$ &, $674^{* * *}$ &,$- 093^{* *}$ &,- 037 &,$- 053^{*}$ &, $137^{* * *}$ &, 036 &,$- 493^{* * *}$ &,$- 409^{* * *}$ &, $818^{* * *}$ & 1 \\
\hline (11) způsob výuky &, $496^{* * *}$ &,$- 113^{* * *}$ &,- 029 &,$- 108^{* * *}$ &, $105^{* * *}$ &, $071^{* *}$ &,$- 419^{* * *}$ &,$- 322^{* * *}$ &, $601^{* * *}$ &, $615^{* * *}$ \\
\hline
\end{tabular}

$* \mathrm{p}<, 05, * * \mathrm{p}<, 01, * * * \mathrm{p}<, 001$

\subsection{TVORBA NOREM}

Po ověření reliability a validity výzkumného nástroje byly pomocí Mc-Callovy plošné transformace vytvářeny normy. Při jejich tvorbě jsme vycházeli z následujících zjištění:

1. Faktorová analýza nevykázala dostatečně silné faktory, normy proto zahrnují dotazník jako celek, který není dále členěn.

2. Párový t-test potvrdil statisticky významný rozdíl mezi hrubými skóry dosaženými v českém jazyce a v matematice, normy proto vznikají pro tyto dva předměty odděleně.

3. Regresní analýza ukázala signifikantní vliv proměnné pohlaví na VAÚ, normy jsou proto vytvářeny zvlášt’ pro chlapce a pro dívky.

4. Regresní analýza ukázala v českém jazyce signifikantní vliv proměnné typ studované školy na VAÚ. Pro přehlednější vyhodnocování testu jsou normy vytvářeny s ohledem na jednotlivé typy středních škol pro oba předměty.

5. Regresní analýza neukázala signifikantní vliv proměnné věk na VAÚ, normy proto nejsou rozděleny dle věku respondentů.

\section{Diskuse}

Hlavním cílem předkládaného výzkumu bylo vytvořit výzkumný nástroj měřící VAÚ u žáků středních škol. Podobný záměr měly ve svých bakalářských pracích také A. Vozková (2014) a B. Ptáčková (2014). Na jejich výzkumy navázala rozsáhlejší studie 
zahrnující žáky čtvrtých a osmých tříd základních škol z několika krajů ČR $(\mathrm{N}=436)$, jejímž cílem bylo vyvinout a ověřit český dotazník matematické self-efficacy pro základní školy (Smetáčková, Vozková, 2016). Dotazník byl jako v našem př́padě tvořen dle doporučení A. Bandury (2006). Tvoří ho 30 tvrzení, s nimiž žáci vyjadřovali svůj souhlas na pětibodové škále. Obdobně jako v našem př́ípadě vykazuje vysokou reliabilitu (Cronbachova alfa $=0,91$ ), faktorovou analýzou byly zjištěny tři faktory.

V př́ípadě našeho dotazníku jsme přijali jednofaktorové řešení, u českého jazyka však bylo možné odlišit rovněž tři faktory. Při srovnání zjištěných faktorů nalézáme podobnost u faktoru námi nazvaného reflexe vlastních schopností (v referenčním dotazníku reflexe schopností), který v obou dotaznících zachycuje přesvědčení respondenta o jeho vlastních schopnostech. Faktor vnitřni motivace (v referenčním dotazníku vliv na výkon, úsili) opět shodně zachycuje stanovování cílů a pokračování po neúspěchu. Ve třetím faktoru se dotazníky rozcházejí. V našem př́padě sytí tento faktor položky zaměřené na strategie rešení problémů. $\mathrm{V}$ referenčním dotazníku se tento faktor rozchází s ohledem na věkovou kategorii. U mladších žáků zahrnuje emočni ladění, u starších dlouhodobý zájem (Smetáčková, Vozková, 2016). Otázkou je, proč faktorová analýza položek našeho dotazníku neumožnila rozdělení do faktorů také v př́ípadě matematiky. Jedno z možných vysvětlení je, že žáci vyplňovali dotazník o matematice až jako druhý. Mohli tedy svým odpovědím věnovat méně pozornosti než $\mathrm{v}$ př́ípadě českého jazyka a získaná data tím mohou být zkreslena.

V našem případě byla validita zjištována pomocí čtyř kritérií (souvislost se školní známkou, hodnocení náročné školní situace, souvislost s prožitky, hodnocení učitelem), která byla splněna. Validita referenčního dotazníku byla posuzována dle rozřazení položek do tří faktorů, které jsou relevantní k teoretickému konceptu VAÚ (Smetáčková, Vozková, 2016). Náš výzkum navíc umožňuje srovnání VAÚ ve dvou předmětech, pro které byl zadáván. V souladu s teorií (Bandura, 1997; Bong, Clark, 1999) se mezi těmito dvěma oblastmi objevil signifikantní rozdíl.

Dále byly zjišt’ovány vztahy s ostatními proměnnými, které lze porovnávat s výsledky předchozích výzkumů. Rozdíly ve VAÚ s ohledem na pohlaví respondentů se zabývala rozsáhlá studie Ch. Huang (2013). Dle metaanalýzy porovnávající 247 nezávislých studií $(\mathrm{N}=68$ 249) je pro zjištování rozdílu VAÚ mezi pohlavími rozhodující především obsah zkoumané oblasti. V souladu s výsledky našeho výzkumu se u dívek objevovala vyšší VAÚ v oblasti jazyků, zatímco u chlapců v oblasti matematiky. Studie dále ukázala, že se rozdíly mezi pohlavími měnily s věkem. Největší rozdíl se objevoval u respondentů nad 23 let. Pro matematiku se signifikantní rozdíly mezi pohlavími ukázaly již v pozdní adolescenci (Huang, 2013). Zmiňovaný český výzkum I. Smetáčkové a A. Vozkové (2016) signifikantní rozdíl mezi pohlavími nezjistil ani u jedné věkové kategorie, což by mohlo být v souladu s výsledky metaanalýzy zapř́íčiněno nízkým věkem respondentů.

V našem výzkumném souboru nebyl zjištěn rozdíl v míře VAÚ $s$ ohledem na věk respondentů. $\mathrm{K}$ podobným závěrům dospěly i tuzemské studie, které se zabývaly změnami VAÚ v přechodových obdobích. V př́ípadě výzkumu B. Kučerové (2015) se jednalo o přechod z prvního stupně základní školy na druhý $(\mathrm{N}=173)$, výzkum S. Lávičkové (2016) pak přechodem ze základní školy na gymnázium $(\mathrm{N}=77)$. Ani v jednom z výzkumů nebyl prokázán statisticky významný rozdíl v úrovni VAÚ s přechodem do vyššího stupně vzdělávání. K jinému závěru však dospěla studie I. Smetáčkové a A. Vozkové (2016), která uvádí výrazně vyšší míru VAÚ v matematice u skupiny žáků čtvrtých tříd, 
oproti třídám osmým $(\mathrm{N}=434, \mathrm{t}=-12,181, \mathrm{p}<, 001)$. Pro potvrzení či vyvrácení vzájemného vztahu VAÚ s věkem žáků je tedy třeba dalšího šetření.

Z hlediska specifických poruch učení a chování se v našem vzorku potvrdila souvislost přítomnosti obtíží a snížení VAÚ. Výraznější vliv poruch se ukazuje v př́ípadě českého jazyka, což pravděpodobně pramení z rozložení jednotlivých obtíží. $Z$ celkového počtu 381 respondentů s obtížemi se v našem vzorku objevilo 172 respondentů s dyslexií a 106 respondentů s dysgrafí́. Dyskalkulii, která by dle našich předpokladů ovlivňovala výrazněji výsledky v matematice, uvedlo pouze 39 respondentů. V českém prostředí se tímto problémem zabývala Z. Táborová (2015), která však nezkoumala VAÚ, ale zůstala na obecnější rovině u vnímané osobní účinnosti. Na výzkumném vzorku, který tvořila již dospělá populace, nebyl zjištěn signifikantní rozdíl mezi zkoumanými skupinami $(\mathrm{N}=1118, \mathrm{t}=0,789, \mathrm{p}=0,432)$. Toto zjištění, které se liší od našich závěrů, může souviset s obsahovým zaměřením vnímané účinnosti, které u nás bylo spojeno prímo se vzděláváním, kdežto ve výzkumu $Z$. Táborové bylo zkoumáno v obecné rovině. Naše výstupy korespondují s izraelskou studií T. Lackaye (2006), která potvrdila signifikantně nižší VAÚ u žákủ sedmých tř̌́d se specifickými poruchami učení oproti žákům bez obtíží $(\mathrm{N}=246, \mathrm{~F}=13,71, \mathrm{p}<, 001)$.

Vzájemnou propojenost školního výkonu a VAÚ potvrzuje mnoho studií. Ve výzkumu K. Özkan (2015) se VAÚ v porovnání se sebepojetím a seberegulací ukázala jako nejdůležitější prediktor akademického výkonu $(\mathrm{N}=130, \beta=0.001, \mathrm{p}<, 05)$. Přehledová studie (Honicke, Broadbent, 2016) zkoumající 95 článků zaměřených na vliv VAÚ na akademický výkon studentů vysokých škol potvrdila korelaci těchto proměnných $(\mathrm{r}=, 33$, $\mathrm{p}<, 001)$. V našem výzkumu byl školní výkon reprezentován školní známkou. Korelace s VAÚ se prokázala v českém jazyce i v matematice, stejně jako v mnoha českých (např. Kučerová, 2015; Lávičková, 2016; Smetáčková, Vozková, 2016) a zahraničních studiích (např. Altunsoy et al., 2010; Caprara et al., 2008; Diseth, 2011). O něco silnější vztah se v našem výzkumu ukázal se známkou, která žákům aktuálně vycházela, signifikantní byl však i vztah se známkou, kterou měli žáci na posledním vysvědčení.

Studie zabývající se souvislostí VAÚ s typem studované školy, spokojeností s výukou předmětu či zajímavostí obsahu předmětu jsme nenalezli, nemůžeme tedy výsledky porovnat. Z hlediska obliby předmětu se naše výsledky shodují se zjištěním B. Ptáčkové (2014), která nalezla statisticky významný vztah VAÚ s oblibou daného předmětu $(\mathrm{N}=55, \mathrm{r}=0,62, \mathrm{p}<, 05)$.

Regresní analýza ukázala silný vliv proměnných obliba předmětu a zajímavost obsahu předmětu na VAÚ. Oblibu předmětu lze spojovat s pozitivními emocemi, které jedinec v daném předmětu prožívá, se zajímavostí obsahu předmětu můžeme spojit pozitivní motivaci. Pozitivní prožitky i zvýšená motivace jsou dle teorie A. Bandury (1997) důsledkem vysoké VAÚ, která vede $\mathrm{k}$ lepším výkonům, které následně VAÚ posilují. Přesný mechanismus vlivu těchto proměnných na VAÚ by však bylo nutné ověřit dalšími výzkumy.

K limitům práce patří zjednodušený model SOU a SOŠ, které byly zastoupeny vždy pouze třemi nejpočetnějšími obory. Pro ověření možných změn výstupů se zařazením dalších oborů je třeba dalšího zkoumání. Kromě rozšíření výzkumu o další obory by bylo jistě zajímavé porovnání informací o VAUU dalších vyučovacích předmětů. Je rovněž možné, že nežádoucí efekt přinesla administrace obou dotazníků najednou. Dotazník pro matematiku byl administrován jako druhý $\mathrm{v}$ pořadí, proto mohou být výsledky v matematice ovlivněny ztrátou zájmu o vyplňování. Aby mohla být tato domněnka vyvrácena, musely 
by být dotazníky administrovány znovu, tentokrát s časovým odstupem. Limitujícím je také zvolená metoda sběru dat, kdy musí být brány v úvahu všechny možné nežádoucí vlivy, které hrají roli při dotazníkovém šetření (předpoklad respondentovy schopnosti introspekce, riziko záměrného zkreslení odpovědí, omezený výběr možností). Pro volbu další intervence by bylo vhodnější rozdělení položek dotazníku do jednotlivých faktorů. V našem výsledném dotazníku jsme o tuto možnost ochuzeni, nicméně vzhledem nízkému počtu položek je v př́padě potřeby možný kvalitativní rozbor.

\section{Závěr}

Cílem předkládaného výzkumu bylo sestavit dotazník měřící VAƯ žáků středních škol. Tento cíl byl naplněn. Podařilo se sestavit dotazník s dobrou reliabilitou i validitou. Výsledná škála měří VAÚ v konkrétním předmětu, pro který je zadána. Vzhledem k formulaci položek se domníváme, že škálu lze použít pro většinu teoretických předmětů. Aktuálně byla testována pro český a jazyk a pro matematiku, pro které také vznikly normy.

V praxi může pedagog, či pracovník školského poradenského zařízení nabízenou škálu využít jako jeden z možných diagnostických nástrojů $\mathrm{v}$ př́ípadě selhávání žáka v některém z předmětů. Zadavatel získá informace o důvěře žáka ve vlastní schopnosti a dovednosti zvládnout nároky daného předmětu, o důvěře ve vlastní schopnosti použít potřebné strategie a připravit se na požadovaný výkon. Tyto aspekty chápeme na základě výsledků faktorové analýzy jako homogenní. Detailnější informace pak může přinést kvalitativní analýza jednotlivých položek dotazníku. Vzhledem ke snadné administraci, rychlému vyplnění i vyhodnocení může být dotazník použit rovněž jako nástroj ke screeningu, $v$ rámci kterého mohou být podchyceni žáci potenciálně ohrožení školním neúspěchem. Pokud bude škála využívána $\mathrm{v}$ praxi, mělo by být její nezbytnou součástí i teoretické osvětlení konceptu a nabídka způsobů posilování VAÚ.

Kromě konstrukce dotazníku přinesl výzkum i další zajímavé informace. Prokázán byl např́íklad statisticky významný rozdíl mezi VAÚ v českém jazyce a v matematice. Analyzovány byly také vztahy mezi VAƯ a dalšími proměnnými (školní známkou, věkem a pohlavím respondentů, specifickými poruchami učení a chování, oblibou předmětu a jinými), které byly porovnány se zahraničními i tuzemskými studiemi.

\section{LITERATURA}

Altunsoy, S., Çimen, O., Ekici, G., Atik, A. D., Gökmen, A. (2010). An assessment of the factors that influence biology teacher candidates' levels of academic self-efficacy. Procedia-Social and Behavioral Sciences, 2(2), 2377-2382.

Bandura, A. (1997). Self-efficacy: The exercise of control. New York: W. H. Freeman and Company.

Bandura, A. (2006). Guide for Constructing Self-Efficacy Scales. In F. Pajares, T. Urdan (Eds.), Self-Efficacy Beliefs of Adolescents (307-367). Greenwich, Connecticut: Information Age Publishing.

Bandura, A., Schunk, D. H. (1981). Cultivating competence, self-efficacy, and intrinsic interest through proximal self-motivation. Journal of Personality and Social Psychology, 41(3), 586-598.

Bong, M., Clark, R. (1999). Comparison between self-concept and self-efficacy in academic motivation research. Educational Psychologist, 34(3), 139-153. 
Bong, M., Skaalvik, E. M. (2003). Academic self-concept and self-efficacy: How different are they really? Educational Psychology Review, 15(1), 1-40.

Caprara, G. V., Fida, R., Vecchione, M., Del Bove, G., Vecchio, G. M., Barbaranelli, C., Bandura, A. (2008). Longitudinal analysis of the role of perceived self-efficacy for self-regulated learning in academic continuance and achievement. Journal of Educational Psychology, 100(3), 25-534.

Diseth, $\AA$. (2011). Self-efficacy, goal orientations and learning strategies as mediators between preceding and subsequent academic achievement. Learning and Individual Differences, 21(2), 191-195.

Draberová, J. (2012). Vnímaná akademická účinnost u žákio středních škol. (diplomová práce), Univerzita Karlova v Praze, Filozofická fakulta, Katedra psychologie.

Honicke, T., Broadbent, J. (2016). Review: The influence of academic self-efficacy on academic performance: A systematic review. Educational Research Review, 17, 63-84.

Hoover-Dempsey, K. V., Sandler, H. M. (2005). The Social Context of Parental Involvement: A Path to Enhanced Achievement. (Final Performance Report for OERI Grant \# R305T010673), Institute of Education Sciences, U.S. Department of Education.

Huang, C. (2013). Gender Differences in Academic Self-Efficacy: A Meta-Analysis. European Journal of Psychology of Education, 28(1), 1-35.

Huerta, M., Goodson, P., Beigi, M., Chlup, D. (2017). Graduate students as academic writers: writing anxiety, self-efficacy and emotional intelligence. Higher Education Research \& Development, 36(4), 716-729.

Jinks, J., Morgan, V. (1999). Children's perceived academic self-efficacy: An inventory scale. The Clearing House, 72(4), 24-230.

Kučerová, B. (2015). Self-efficacy v tranzitornich momentech se zaměřením na přechod mezi prvním a druhým stupněm základniho vzdělání. (diplomová práce), Univerzita Karlova v Praze, Filozofická fakulta, Katedra psychologie.

Lackaye, T., Margalit, M., Ziv, O., Ziman, T. (2006). Comparisons of Self-Efficacy, Mood, Effort, and Hope between Students with Learning Disabilities and Their Non-LD-Matched Peers. Learning Disabilities Research \& Practice, 21(2), 111-121.

Lávičková, S. (2016). Proměny vnímané akademické účinnosti při přechodu na střední školu. (diplomová práce), Univerzita Karlova v Praze, Filozofická fakulta, Katedra psychologie.

Marsh, H. W., Hau, K.-T., Artelt, C., Baumert, J., Peschar, J. L. (2006). OECD's Brief Self-Report Measure of Educational Psychology's Most Useful Affective Constructs: Cross-Cultural, Psychometric Comparisons Across 25 Countries. International Journal of Testing, 6(4), 311-360.

Ministerstvo školství, mládeže a tělovýchovy (2015). Statistické ročenky školství-výkonové ukazatele. [Vyhledáno 5.6.2015 na http://toiler.uiv.cz/rocenka/rocenka.asp]

Muris, P. (2001). A brief questionnaire for measuring self-efficacy in youths. Journal of Psychopathology and Behavioral Assessment, (23), 145-149.

Özkan, K. (2015). The Interplay Among Academic Self-Concept, Self-Efficacy, Self-Regulation and Academic Achievement of Higher Education L2 Learners. Yüksekögretim ve Bilim Dergisi, 5(1), 32-40.

Pastorelli, C., Caprara, G. V., Barbaranelli, C., Rola, J., Rozsa, S., Bandura, A. (2001). The structure of children's perceived self-efficacy: A cross-national study. European Journal of Psychological Assessment, 17(2), 87-97.

Pintrich, R. R., DeGroot, E. V. (1990). Motivational and self-regulated learning components of classroom academic performance. Journal of Educational Psychology, (82), 33-40.

Poynton, T. A., Carlson, M. W., Hopper, J. A., Carey, J. C. (2006). Evaluation of an innovative approach to improving middle school students' academic achievement. Professional School Counseling, 9(3), 190-196.

Ptáčková, B. (2014). Self efficacy divek a chlapců v matematice v období adolescence. (bakalářská práce), Univerzita Karlova v Praze, Pedagogická fakulta, Katedra psychologie.

Roick, J., Ringeisen, T. (2017). Self-efficacy, test anxiety, and academic success: A longitudinal validation. International Journal of Educational Research, 2017(83), 84-93.

Schunk, D. H. (1984). Sequential attributional feedback and children's achievement behaviors. Journal of Educational Psychology, 76, 1159-1169.

Smetáčková, I., Vozková, A. (2016). Matematická self-efficacy a její měření v průběhu záklandí školy. E-psychologie, 10(1), 18-33.

Táborová, Z. (2015). Specifické obtiže dospělých s dyslexii. (diplomová práce), Univerzita Karlova v Praze, Filozofická fakulta, Katedra Psychologie. 
Vozková, A. (2014). Self-efficacy v matematice u žáků a žákyň prvního stupně ZŠ. (bakalářská práce), Univerzita Karlova v Praze, Pedagogická fakulta, Katedra psychologie.

Williams, T., Williams, K. (2010). Self-efficacy and performance in mathematics: Reciprocal determinism in 33 nations. Journal of Educational Psychology, 102(2), 453-466.

Zimmerman, B., J., Bandura, A. (1994). Impact of self-regulatory influences on writing course attainment. American Educational Research Journal, 31, 845-862.

\section{ACADEMIC SELF-EFFICACY AT HIGH SCHOOL STUDENTS IN CZECH LANGUAGE AND MATHEMATICS, RESEARCH TOOL DEVELOPMENT}

\section{J. DRABEROVÁ}

\section{ABSTRACT}

The aim of this study was to develop a research tool for assessing high school students' academic self-efficacy, which is not yet available in the Czech environment. The research sample consists of 1717 high school students from all regions of the Czech Republic. The research included secondary vocational schools and grammar schools. Pupils filled in the questionnaire for Czech language and for mathematics. The final research tool is highly reliable and also its validity has been verified. Furthermore, the significant relationship between measured academic self-efficacy and the popularity of the school subject was found. Also the link with the school grade, the type of school, specific learning and behavioral disorders and other variables was confirmed.

Keywords: academic self-efficacy, self-efficacy, scale development, high school, Czech language, mathematics

O autorce: Mgr. et Mgr. Jana Draberová: Pracuje v Pedagogicko-psychologické poradně pro Prahu 11 a 12, je doktorandkou na katedře psychologie Filozofické fakulty Univerzity Karlovy. Univerzita Karlova, Filozofická fakulta, katedra psychologie; Pedagogicko-psychologická poradna pro Prahu 11 12.E-mail:draberovaj@seznam.cz

Výzkum byl podpořen Grantovou agenturou Univerzity Karlovy (projekt č. 127415). 